\title{
NARRATIVE AND CONTEMPORARY POETRY
}

\section{Neil Roberts*}

Abstract: Contemporary narrative poetry presents a challenge to the teacher: how to approach it from a narratological perspective and still pay attention to the details of poetic language? This essay uses a Bakhtinian approach to explore the generic experiments of five contemporary poets: Tony Harrison, Derek Walcott, Peter Reading, Ted Hughes and Anne Stevenson.

Keywords. Poetry; Narrative; Intertextuality; Bakhtin; Contemporary poets

The long poem in the modernist period is notoriously fragmented, in respect of narrative elements as in other respects. It invites - indeed it played an important part in cultivating - the kind of intensive close reading practised in academic criticism and the teaching of English and American literature in the mid twentieth century, and is at least more immediately rewarding in its parts than in its wholes. In the contemporary period (which for the purposes of this essay is approximately the last thirty years) poets have shown more faith in narrative and surface coherence. The poems that I will be considering in this essay, by Derek Walcott, Ted Hughes, Tony Harrison, Anne Stevenson and Peter Reading, may seem formally conservative by comparison with Eliot, Pound and Williams; by comparison with most of the mainstream literary prose fiction of the period, however, they are highly experimental in their handling of genre.

For the teacher of literature, these texts present a dilemma. While some of them undoubtedly contain passages that reward the kind of analysis traditionally devoted to poetry, others do not, and whether they do or not, such analysis does not address the structural and generic distinctiveness of the poems. On the other hand, the kind of narratological analysis that one might devote to a novel tends to ignore the distinction between verse and prose.

My approach to this dilemma might seem paradoxical, since it involves using a theorist, Mikhail Bakhtin, who notoriously privileged the novel over

Neil Roberts is Professor of English literature at 'The University of Sheffield, England, and is the author of Narnatic and l hix in Postmur Poetry (Longman, 1999) and books on (ieorge Liliot, Ted Hughes, Peter Redgrove, George Mcredith and D. II. I awrence. I Ic is also the editor of a Companion to Tiventicth Century Poutry (Blackwell. 2(0)1) and currently working on a literary life of Ted Hughes. 
poetry, and once used Evgenij Onegin as his prime example of novelistic discourse, without acknowledging that it is a poem (Bakhtin, 1981, 41-83). Bakhtin wrote that 'The novel can be defined as a diversity of social speech types... and a diversity of individual voices, artistically organised', whereas in poetry 'the unity of the language system and the unity (and uniqueness) of the poet's individuality as reflected in his language and speech... are indispensable prerequisites' (Bakhtin, 1981, 262, 264). Whereas the novel is dialogic, poetry is monologic, and these are not merely descriptive but evaluative terms in Bakhtin: the former characterises the diversity of actual social life; the latter, ultimately, the totalitarian state.

Despite this curious exclusion of poetry from the most vital resources of language, several recent critics of contemporary poetry have found Bakhtin useful (Gregson, 1996, Kennedy, 1996, Roberts, 1999). Bakhtin himself acknowledges in a footnote that he is characterising an 'extreme' of poetic discourse, and that 'in concrete examples of poetic works it is possible to find features fundamental to prose' (Bakhtin, 1981, 287). In a century whose idea of poetry may be said to have been inaugurated by The Waste Land, the notion that poetry is characterised by 'the poet's individuality as reflected in his language and speech' is clearly inadequate. More positively, Bakhtin's definition of his central concept, dialogism, has a special relevance to poetry:

The word, directed towards its object, enters a dialogically agitated and tension-filled environment of alien words, value judgements and accents, weaves in and out of complex interrelationships, merges with some, recoils from others, intersects with yet a third group: and all this may crucially shape discourse.(Bakhtin, 1981, 276)

Bakhtin's account of the life of language is characteristically conflictual. Words exist 'in other people's mouths, in other people's contexts, serving other people's intentions: it is from there that one must take the word, and make it one's own' (Bakhtin, 1981, 294). In no literary context is this more demonstrably true than in poetry. It is no accident that Harold Bloom developed his theory of writing as the struggle with the precursor with reference to poetry. Consider Ted Hughes's description of poetic tradition as a 'maternal octopus' (Faas, 1980, 201) or Tony Harrison's defiant announcement 'So right, yer buggers, then! We'll occupy/ your lousy leasehold Poetry' in his poem 'Them \& [uz]'.

This is of course an aspect of intertextuality. Intertextual relationships are especially important in the texts I am discussing in this essay: Walcott's Omeros and Reading's Ukulele Music to Homer, Hughes's Gaudete to Euripides, 
Harrison's v to Thomas Gray, Stevenson's Correspondences to various discourses of American Puritanism, and to Sylvia Plath. In these texts also, narrative is in dialogue with other modes - autobiographical reflection in Walcott and Harrison, lyric in Hughes, letters in Stevenson and Reading - and, in most of them, verse is in dialogue with prose. Narrative, of a developed and coherent kind, is central to them all, but it is disrupted, brought into question or subordinated to some other mode. 'Poetry' in the sense of verse-writing is not only central but highly self-conscious, to the point, in several texts, of being itself a thematic element. In this essay I will not be offering complete critical accounts of any of these texts, but discussing key aspects each of them, which can provide the focus for discussion in class of issues of poetic form, narrative and dialogism.

Tony Harrison's $v$. is a personal and political meditation set in a graveyard (the resting place of his parents) within which is embedded a vivid narrative episode. The setting of the poem and its verse form-alternately rhyming quatrains in iambic pentameter-obviously invoke Gray's Elegy. In most other respects the poem offers a marked contrast to Gray: the earlier poem is a lament for the unfulfilled lives of the nameless dead who lie in unmarked graves; in Harrison's poem the common people, the butchers, publicans and bakers, are named and their achievements memorialised. The speaker is self-consciously a poet (or, as he puts it, 'bard') but he tries to pass off his poetry-making as a trade like theirs, and looks forward to being buried with them. The language of Harrison's poem is for the most part in marked contrast to Gray's Augustan elegiac, even before the notorious obscenities erupt into it. The very first line, Next millennium you'll have to try quite hard', challenges the reader to scan it as an iambic pentameter, which is, however, the metrical norm for the poem. However, at moments Harrison rises to, or lapses into, a diction and rhythm that in isolation one would confidently assign to the eighteenth-century: 'a blackened dynasty of unclaimed stone... the hymnal fragments and the gilded prayer.'

There is no air of parody about such lines: the poet seems on good terms with his eighteenth-century precursor. The poem opens with a long meditation, influenced by Gray, on the graves, their inscriptions, and most of all on the graffiti that have been sprayed on them, which is brought to an abrupt conclusion:

\footnotetext{
What is it that these crude words are revealing?

What is it that this aggro act implies?

Giving the dead their xenophobic feeling

or just a cri-de-coeurbecause man dies?
} 
So what's a cri-de-coeur, cunt? Can't you speak the language that yer mam spoke. Think of 'er! Can yer only get yer tongue round fucking Greek? Go and fuck yourself with ini-de-ioent!

The interlocutor is a 'skinhead', a representative of those who have vandalised the graves. He re-accents the poet's words and challenges his credentials to speak for his class. Despite his strong Leeds dialect, he does so in skilful and articulate verse. It is no shock when he turns out to have the poet's name, because he is finally an aspect of Harrison's poetic persona. The conflict between poet and skinhead is centrally a matter of language, or of what Bakhtin called heteroglossia, 'the social diversity of speech types' (Bakhtin, 1981, 263). The relation between these speech-types is one of conflict, and in this poem it is a conflict in which the skinhead always wins, as in the above example or:

I wish on this skin's words deep aspirations, first the prayer for my parents I can't make, then a call to Britain and to all nations made in the name of love for peace's sake.

Aspirations, cunt! Folk on t'fucking dole 'ave got about as much scope to aspire above the shit they're dumped in, cunt, as coal aspires to be chucked on t'fucking fire.

By contrast, the poet's attempts to appropriate and reaccent the skinhead's words are weak, and invariably trumped by the skinhead:

'Listen, cunt!' I said, 'before you start your jeering the reason why I want this in a book

's to give ungrateful cunts like you a hearing!'

A book, yer stupid cunt, 's not worth a fuck!

Walcott's Omeros has much in common with $v$. Like Harrison's poem it alludes to and engages with (more overtly) a canonical precursor, is written in sustained formal verse which is an aspect of this engagement and allusion, and has a consistent narrative voice that is at least partly identified with the autobiographical poet. It is like $v$ also in combining narrative with and ultimately subordinating it to a more reflective mode of writing. Walcott's engagement with Homer is however more bold and momentous than Harrison's with Gray. Harrison may have his skinhead say, 'Don't talk to me of fucking representing/ the 
class yer were born into any more', but in Walcott's case it is real critics out in the world who write in the following manner:

Derek Walcott is a poet who has been picked up by the western intelligentsia as the poetic genius of the Third World... He has appealed from the beginning to foreign critics and foreign needs. Poetry is history and ideology, and Walcott's figure in the Caribbean plays to the belief that colonization brought civilization, brought culture. (Brand, 1984-5, 26)

The extensive allusion to Homer (and the more implicit nod to Dante in the use of tera rima) in Omeros may be grist to this kind of critique. Alternatively it could be seen as an example of what Gareth Griffiths calls the possibilities for the hybridised subjects of the colonising process to legitimate themselves or to speak in ways which menace the authority of the dominant culture precisely in so far as it "mimics" and so subverts it' (Griffiths, 1995, 241). I think Walcott would reject this description as much as the other. He has written in his essay "The Muse of History',

In the New World servitude to the muse of history has produced a literature of recrimination and despair, a literature of revenge written by the descendants of slaves or a literature of remorse written by the descendants of masters. Because this literature serves historical truth, it yellows into polemic or evaporates in pathos. (Walcott, 1998, 37)

Walcott's use of Homer is neither cringe nor menace, both equally the results of an historical determinism that he rejects, but a sense of affinity and ownership. His Homer is 'the poet of the seven seas', who speaks to the Caribbean as much as to the Aegean (Bruckner ,1993, 396). This does not mean, however, that there is no tension in Walcott's relation to Homer. In the same essay he suggests that the muse of history may also be the muse of epic poetry:

The epic-minded poet looks around these islands and finds no ruins, and because all epic is based on the visible presence of ruins, wind-bitten or sea-bitten, the poet celebrates what little there is, the rusted slave wheel of the sugar factory, cannon, chains, the crusted amphora of cut-throats, all the paraphernalia of degradation and cruelty which we exhibit as history, not as masochism, as if the ovens of Auschwitz and Hiroshima were the temples of the race. (Walcott, 1998, 44) 
Omeros is not an epic poem. Its relationship to the Iliad is quite different from that of Ulysses to the Odyssey. Walcott's poem opens with an episode in which two St Lucian fishermen, Achille and Hector (their Homeric names given plausibility by the French colonial custom of giving their slaves classical names) quarrel ostensibly about a rusty tin but really about a woman, Helen. This obviously echoes the opening of the Iliad, in which Achilles and Agamemnon quarrel about a woman. But the names of the protagonists even more obviously associate them with the Greek and Trojan heroes whose fight is the climax of the epic. Furthermore, the fact that they are quarrelling over Helen identifies them with another pair, Menelaus and Paris, whose dispute is the cause of the war. The episode seems to inaugurate a narrative that will, like Ulysses, structure itself on Homer; in fact the whole of the Iliad is as it were condensed in it, leaving Walcott free to use Homer as he wishes.

The Homer with whom Walcott feels an affinity is the author not of the bloodthirsty and 'historical' epic the Iliad, but of the Odyssey: "epic" makes people think of great wars and great warriors. That isn't the Homer I was thinking of; I was thinking of Homer the poet of the seven seas' (Bruckner, 1993, 396). His hero Achille thus becomes the homeward-travelling Odysseus: 'And I'm homing with him, Homeros, my nigger!' (Walcott, 1990, 159)

Allusion to and ultimately rejection of the narrative model of the epic is one way in which intertextuality is evident in Omeros. Another is verse form. A narrative poet needs a line which will foster both the local in tensities of poetic language and the momentum of narration (as Hughes put it, 'that would go from beginning to end in some forceful way... while being written in the kind of verse that would stop you dead at every moment' [Faas, 1980, 214]). Traditionally English poets have used the iambic pentameter for this purpose. Harrison follows this tradition in $v$. The iambic pentameter is a flexible and prose-like line. Almost invariably the formal five-stress pattern is counterpointed by a 'natural' four-stress pattern, one of the five stresses being significantly weaker that the others. The weaker stress may occur at different points in the line, giving great flexibility and variety. The classic account of this is in Northrop Frye's Anatomy of Criticism (Frye, 1957, 251ff). Classical epic poetry is written in hexameters: dactyls and spondees which can be combined in various ways, similarly achieving variety. In Omeros Walcott has devised a verse-form that synthesises these two. The poem is written in iambic hexameters. This line, under the name of Alexandrine, figures in Spenserian stanzas and occasionally in Augustan couplets. The traditional Alexandrine has a marked caesura, dividing into two trimeters. The pentameter thus seems 
to be the limit of the single metrical unit in English poetry. But Walcott has devised a hexameter that is like a pentameter, that does not have an invariable caesura and that counterpoints six metrical stresses against a 'natural' five:

His shipmates watched him, then they hooked hands like anchors

under the hulls, rocking them; the heels sheared dry sand till the wet sand resisted, rattling the oars

that lay parallel amidships; then, to the one sound of curses and prayers at the logs jammed as a wedge, one after one, as their tins began to rattle,

the pirogues slid to the shallows' nibbling edge, towards the encouraging sea. (Walcott, 1990,10)

In his essay, 'The Caribbean: Culture or Mimicry?', Walcott took issue with V.S. Naipaul's notorious assertion that everything in the Caribbean is 'mimicry, uncreative'. Walcott retorted by proposing a strong concept of mimicry epitomised by Carnival, whose 'forms originated in imitation if you want, but ended in invention... Mimicry is an act of imagination' (Walcott, 1974,19). Both in its relation to classical epic and in its verse form, which as it were fuses the examples of Homer and Milton, Omeros exemplifies Walcott's description of the cultural products of the West Indies: 'like nothing one has ever seen before' (Walcott, 1974, 16).

From Walcott to Peter Reading seems a vertiginous leap. Whereas Walcott (and Harrison and Hughes) identifies themselves as poets in the most traditional, valorised sense, Reading has said, 'I don't want to offend anybody by appearing to think of myself as a poet, really, because I don't' (Jenkins, 1985, 7). His books are full of reflexive comments like this from his sequence $C$ :

verse is for healthy

arty-farties. The dying

and surgeons use prose (Reading 1995, 277)

(which, with characteristic doubled reflexiveness, is of course a haiku). The figure of the poet in Walcott and Harrison has strong autobiographical resonances. In Ukulele Music (1989), the text on which I shall be concentrating, Reading's 'poet' is a self-consciously fictive figure who derives his knowledge of the real world from newspapers and notes left by his cleaner.

Between 1984 and 1989 Reading published four volumes (C, Ukulele Music, Final Demands and Perduta Gente) in which starkly contrasting textual units are combined 
to produce an often obscure and unresolved but unquestionably present and structuring narrative. These volumes are also characterised by the self-conscious foregrounding of formal devices: $C$ consists of a hundred hundred-word units, in prose and various kinds of verse; the other volumes all make extensive use of imitations of classical metre, especially elegiac distich and alcaics. The key Bakhtinian concept here is polyphony: 'a plurality of independent and unmerged voices and consciousnesses' not subordinated to the consciousness of the author (Bakhtin $1984,6)$. The first of Ukulele Music's three parts consists of alternating sections supposedly written by the poet and his cleaner, Viv. The poet's sections are rants about the state of society, in elegiac distich. Viv's are notes vritten to him in misspelt and ungrammatical prose, which narrate episodes of her experience that are subsequently incorporated in the poet's verse. Though all her writing is addressed to him, he never addresses her or overtly acknowledges her existence. The second part, in a looser form of verse, consists of a series of nautical tales told by a demented sea-captain as if they were his own experience. One of these tales however, the witnessing of the atomic bomb at Bikini, might really be his experience.

The third part opens with the voice of Viv in elegiac distich:

Who would have thought it, Sir, actually putting ME in a WRITING!

Me and the Capting and ALL. What a turn up for the books. (Reading 1996, 34)

In Tony Harrison's parlance, Viv 'occupies' the textual territory hitherto exclusive to the poet, who 'employs' not only her cleaning services but her life experience. The poem's narrative is thus partially enacted at the textual level. During this third part a fourth voice, that of a maddeningly inane ukulele instruction manual, enters the poem, and by its end all four voices combine in a literal polyphony:

bend ye now three lower storm-staysails and a storm spanker, mister,

take in the three up.er tops, close-reef the foresail, F sharp,

tighten the $B$ string and place finger at the back of the second fret of the A string and keep spondees and dactyls close-clewed,

trim yr heroic hexameter (or it may be dactylic), splice the pentameter aft, finger yr frets as ye go

surely we shouldn't be speaking like this sir, not in Allergic Dis Talk, taint natural-like: I'm goin back to me prawse (Reading 1996, 43) 
By the end of the poem its 'characters' are confined together in a nuclear bunker. The passage underground has been narrated by means of a direct translation of the voyage to the underworld in the Odyssey.

Reading uses formal metre in a very different spirit from Harrison and Walcott. Harrison's quatrains, as we have seen, embody a strong and by no means entirely adversarial relationship with the canon of English poetry. He has also said that he is attracted to metrical verse because of its association with the rhythms of the body (Haffenden 1991, 236). Walcott's hexameters are his own invention, but they signify a similar relationship not only to English but to classical poetry. The only poet who has significantly anticipated Reading's metres is Arthur Hugh Clough; but Clough was writing for a readership that was familiar with classical poetry. Reading does not himself read Greek, nor do the vast majority of his readers; despite his imitation of Odysseus's descent to Hades in Ukulele Music (and his shipwreck on Phaeacia in Final Demands), Reading's metres do not in themselves signify any intertextual relationship with classical poetry: they do not summon any ghosts or 'maternal octopuses'. Reading's use of metre is overtly and self-consciously ludic, as in these lines from 'Going On':

Bit of a habit, the feigned indignation, various metres, Alcmanics and so forth, ludic responses to global débâcles.

Just Going On remains possible through the slick prestidigital art of Not Caring/Hopelessly Caring. (Reading, 1996, 76)

As the title of Ukulele Music suggests, the maddening voice of the ukulele manual ('For accompanying singing, the haunting harmony of the Uke has no superior! Soft summer nights and the Uke are inseparable pals! Reading 1996,40 ) is a reflection on the poet's own practice, as is the song referred to by Viv as 'he play his Youkalaylee while the ship went down' (Reading 1996 15). This is confirmed by the final lines of the text:

plinkplinka : plinkplinka : plinkplinka : plinkplink i plinkplinka : plinkplink

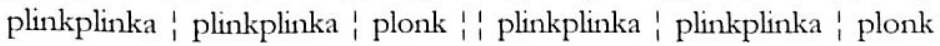

Ted Hughes's Gaudete (1977) was possibly the worst received of all his volumes of poetry. Martin Dodsworth's review was typical: 'Hughes can't and won't think... Gaudete, simply, is a fantasy that has enslaved its creator' (Dodsworth, 1977). Terry Eagleton's response was more precise and thoughtful, but still came down to accusing the poem of being fundamentally 
inartistic: 'one never has the feeling... that Hughes's language self-reflectively takes the measure of its own limits and capabilities.... Hughes's language... is insufficiently inflected and articulated... Hughes's language fails to assume any attitude to what it speaks of' (Eagleton, 1978, 78-79). Gaudete tells a bizarre story of usurped identity, transportation to the spirit world, a charismatic religious cult, drug-induced ritual orgies and mob violence, set in a picturepostcard English village. The story is told in what Hughes himself called a 'headlong' (Hughes, 1978) style, in the present tense, with episodes strung together and narrated entirely as what Genette called 'scene'-when the narration and the events narrated supposedly take the same time-or even the unusual mode that Genette didn't recognise but Chatman called 'stretch', when the narration takes longer than the events narrated. There is no 'summary', no explicit linking of events; the reader is immersed in a continuous present and, usually, in the subjectivity of one or other character who is experiencing that present. Hughes himself described it as follows:

My main problem was to make the implications of my theme clear, and yet at the same time make no authorial comment, no exposition, permit no discussion between characters and permit them no individual speculation that was not an organic part of enactment, and that didn't contribute to a sense of claustrophobic involvement. (Hughes 1978)

There is an almost complete lack of dialogue, but Hughes also stated that 'at every point the intonation of the language becomes infected by the tempo and style of whatever character it's dealing with at the time' (Hughes 1978). This sounds very like a formulation of Bakhtinian polyphony, but most readers feel that the narrative style is in fact tyrannical and monologic.

There are many possible valid critical responses to this text, but they do not include the accusation that it is an unthinking fantasy, or that the language is not conscious of itself. Furthermore, there are significant elements of intertextuality and generic dialogism in the text that attest to its highly conscious character. The story is a distorted version of The Bacchae. The vicar of the parish, the Reverend Lumb, has been usurped by an 'elemental nature spirit' in his form, who seduces all his female parishioners and turns the Women's Institute into a theriomorphic sexual orgy, at which fly agaric sandwiches are served. Although the poem never adopts an overtly comic tone, much of it is very funny, and it would be unwise to assume that the poet is unaware of this: Hughes is a master of straight-faced, sinister humour. The 
narrative ends with Lumb being hunted down by the men of the parish and shot dead. In The Bacchae Dionysos takes revenge on his antagonist Pentheus by making him mad, inducing him to dress in women's clothes and infiltrate the rituals of the god's female followers. The consequence is that Pentheus is hunted down and torn to death by his own mother. Two striking differences between Hughes's poem and Euripides's play highlight important aspects of the former. On is that, although Hughes's story is a supernatural one, and the 'original' vicar has been abducted to the 'spirit world' (which is a very visceral place) while the nature spirit usurps his life, there is no god controlling the world of the story: the rent in the material lives of the villagers results in a destructive chaos which Lumb no more than anyone else can control; whereas the violence in The Bacthae is precisely the will of the god. The second difference is that Lumb is hunted down and destroyed by men, not women. As in Hughes's other major works of the 1970s, Crow and Cave Birds, an important part of what is at issue is masculinity.

The strongest evidence for the artistic consciousness of Gaudete, however, is its 'Epilogue'. This consists of forty-five short poems sup posedly written by the 'original' Lumb and addressed to 'a nameless female deity'. Hughes has written of the 'unwritten half of Gaudete', which is 'what happened to Lumb in "the other world", and described the actual narrative as 'a parallel, but with all the episodes inverted and as it were depraved' (Hughes 1978). But the other half is not unwritten: it is the Epilogue. It is unwritten as narrative, but written as lyric. More than half these poems are formally apostrophic. Jonathan Culler has written very illuminatingly about the tension between apostrophe and narrative: apostrophe invokes 'a detemporalised space'; it 'substitutes a temporality of discourse for a referential temporality', most obviously by addressing someone who is dead, absent or lost as if s/he were present (Culler 1981, 150). If the Epilogue stands for what Hughes called 'the unwritten half' it is not commensurable with the other half: lyric has been substituted for narrative, a temporality of discourse for a referential temporality, one is tempted to say a sacred consciousness for a profane one. The implication is that 'what happened to Lumb in the "other world" is strictly not narratable.

The other significant aspect of the Epilogue poems is that they are written in a very different style from that of narrative. In place of the 'headlong', paratactic, unreflective style of the narrative we have a much more inward, complex, hypotactic language (one of the best of the poems, 'I know well', has two main clauses, five subordinate clauses and four participle phrases dependent on subordinate clauses in its seventeen lines, Hughes, 1977 190- 
91). The two parts of the poem are stylistically as well as generically in dialogue with each other, and the poem's consciousness, artistic as well as ideological, is in this dialogue.

Anne Stevenson's Correspondences (1974) has the subtitle, A Family History in Letters'. This immediately signals a generic complexity that is potentially, in Bakhtin's sense, dialogic. 'Family History' evokes the kind of seamless narrative epitomised by The Forsyte Saga. Correspondences covers a period of 150 years and the events it alludes to-fortunes made and lost, adultery and divorce, deaths by shipwreck, war and cholera, madness in more than one generation-are the stuff of a popular novelistic genre that might be called the 'family history blockbuster'. But Correspondences takes a very tangential approach to these events. They are mostly not narrated, but implied by the epistolary mode. In an essay reflecting on Correspondences, Stevenson has asked, 'Why had no one thought of writing an epistolary poem before?' (Stevenson $1979,169)$. This was not such an innovation as she thought-Clough wrote one in Amours de Voyage-but Stevenson is right to emphasise the importance of the generic cross. An epistolary poem is not just an epistolary novel in verse: the representation of 'letters' in verse entails a tension between the two aspects of the genre, much more strongly and obviously than in the epistolary novel. The focus is consistently on language, or discourse.

The generic tension also harks back to Bakhtin's (admittedly antiquated and inadequate) conception of poetic discourse as the poet's individuality as reflected in his language and speech (Bakhtin 1981, 264). Correspondences is partly in dialogue with the work of another poet, contemporary with Anne Stevenson, also an American who married an Englishman and settled in England-Sylvia Plath. The naively confessional notion that in Plath's poetry we are witnessing her psyche spilt on the page has been challenged by critics such as Jacqueline Rose and Tracey Brain. However, this myth was very powerful in the context in which Stevenson was writing in the early 1970s, and she herself has explicitly rejected what she called Plath's 'unique brand of romantic extremism' and the assumption that "who am I?" is the primary question' (Stevenson 1990, 19).

I will give just one example of the way in which the poetic and the epistolary interact in this text, and of how consequently the poetic does not have the status of a unique, individual voice, but is dialogically questioned and contextualised.

The history with which Correspondences engages is that of Puritan New England, and the various ways in which the Puritan heritage influences different 
generations. One early 'character' is Reuben Chandler, the son of the uncompromising Calvinist pastor, Adam Ezekiel Chandler. Reuben runs away from home and college, and subsequently repents, writing to his father, supposedly in 1832, in this style:

The road I follow with my eyes, head

Lowered, afraid to look up or to the

Right or left, though I feel,

Like a palpitating veil,

The thick vegetation of the Bayou

Looming from its moss;

The fierce, silent pulse of the

Mississippi. (Stevenson 1996, 223)

This is unmistakably twentieth century American poetry. The verse form is William Carlos Williams's invention, the 'variable foot'. The diction ('a palpitating veil', 'fierce, silent pulse') and the hesitant effect produced by the enjambement are equally signatures of modernity. The effect is completely anachronistic: nobody could suppose that this was really written by a repentant Puritan Prodigal Son in 1832. If the whole poem were written in this manner, the reader would accept it as a literary convention, and the verse form would, after a while, cease to be an issue. But the whole poem is not written in this manner. Here is a letter from Reuben's father, the pastor, to his daughter, on the occasion of her husband's death by shipwreck:

What your conduct has been your conduct will teach you. What God in his Justice has performed is plain enough. Is it possible you imagine you have chaims on his Infinite Mercy? (Stevenson 1996, 218-9)

The rhythm and diction of this are obviously pastiche, and the verse form does not intrude at all on the verbal image of an early nineteenth century Puritan. Clearly these passages have different relationships to the present of writing, and to the authorial consciousness. But to say that one is pastiche does not imply that the other is somehow 'authentic'. The anachronistic attribution of post-Williams verse to 'Reuben Chandler' brings that verse forward to our attention, makes us aware of its own cultural boundedness and artificiality.

The narrative poem in the last three decades of the twentieth century threw up some of the most genuinely experimental texts of the period. They 
challenge the boundaries of genre, and force attention on the relationship between genre and language. The necessity for close reading, combined with an awareness of narrative theory, make these texts exceptionally stimulating to teach, especially to more advanced students.

\section{WORKS CITED}

Bakhtin, M.M. The Dialogic Imagination, ed. Michael Hoquist, tr. Caryl Emerson and Michael Holquist, Austin: University of Texas Press, 1981.

Bakhtin, Mikhail. Problems of Dostoevsky's Poetics, ed. and tr. Caryl Emerson, Minneapolis: University of Minnesota Press, 1984.

Brand, Dionne. 'The Caribbean', Poetry Canada Review, 6, 1984-5.

Bruckner, D.J.R., 'A Poem in Homage to an Unwanted Man', Robert D. Hamner, ed., Critical Perspectives on Derek Walcott, Washington D.C.: Three Continents Press, 1993.

Culler, Jonathan. The Pursuit of Signs. London, Routledge and Kegan Paul, 1981.

Dodsworth, Martin. Review of Gaudete. Guardian, 19 May 1977.

Eagleton, Terry. Review of Gaudete. Stand, vol. 19, no.2, 1978, p.78-79.

Faas, Ekbert. Ted Hughes: The Unaccommodated Universe. Santa Barbara: Black Sparrow Press, 1980.

Frye, Northrop. Anatomy of Criticism. New Jersey: Princeton University Press, 1957.

Gregson, Ian. Contemporary Poetry and Postmodernism: Dialogue and Estrangement, Basingstoke, Macmillan and New York: St Martin's Press, 1996.

Griffiths, Gareth. 'The Myth of Authenticity', Bill Ashcroft, Gareth Griffiths and Helen Tiffin, eds. The Post-Colonial Studies Reader, London and New York: Routledge, 1995, p.237-41.

Haffenden, John. 'Interview with Tony Harrison', Neil Astley, ed., Tony Harrison: Bloodaxe Critical Anthologies: 1. Newcastle upon Tyne: Bloodaxe, 1991.

Harrison, Tony. Selected Poems ( $2^{\text {nd }}$ edition), Harmondsworth: Penguin, 1987. 
Hughes, Ted. Gandete, London: Faber 1977.

Hughes, Ted. Unpublished Letter to Neil Roberts and Terry Gifford. October 1978

Jenkins, Alan. 'Making Nothing Matter: Peter Reading talking to Alan Jenkins'.

Poetry Review, vol.75, n0.1, 1985, p.5-12

Kennedy, David. New Relations: The Refashioning of British Poetry 1980-199. Bridgend: Seren, 1996.

Reading, Peter. Collected Poems 1: Poems 1970-1984. Newcastle upon Tyne: Bloodaxe, 1995.

Reading, Peter. Collected Poems 2: Poems 1985-1996. Newcastle upon Tyne: Bloodaxe, 1996.

Roberts, Neil. Narrative and Voice in Postwar Poetry. Harlow: Alison Wesley Longman, 1999.

Stevenson, Anne. 'Writing as a Woman', Mary Jacobus, ed., Women Writing and Writing about Women. London and Sydney: Croom Helm, 1979, p.159-76

Stevenson, Anne. 'Sylvia Plath and the Romantic Heritage', PN Review vol.16.no.6, 1990, p.18-21.

Stevenson, Anne. The Collected Poems 1955-1995, Oxford: Oxford University Press, 1996.

Walcott, Derek. 'The Caribbean: Culture or Mimicry?' Journal of Interamerican Studies and World Affairs 16, 1974.

Walcott, Derek. Omeros. London: Faber, 1990.

Walcott, Derek. What the Twilight Says. London: Faber, 1998. 